This article has been published in a revised form in The Historical Journal https://doi.org/10.1017/S0018246X2100025X. This version is free to view and download for private research and study only. Not for re-distribution, re-sale or use in derivative works. (C) The Author(s), 2021. Published by Cambridge University Press.

TROPICAL HOSPITALITY, BRITISH MASCULINITY AND DRINK IN LATE EIGHTEENTH-CENTURY JAMAICA

TREVOR BURNARD

\title{
UNIVERSITY OF HULL
}

Abstract: White Jamaicans developed a drinking culture that drew on British precedents, but which mutated in the tropics into a form of sociability different from how sociability operated in mid-eighteenth Enlightenment Europe, where civility was a much aspired to norm. In this essay, I use works by eighteenth-century social commentators on Jamaica - Edward Long and especially J.B. Moreton - to explore how white Jamaicans developed a form of sociability which in Long was praised as showing Jamaicans as a generous and hospitable people but which in Moreton was described, more accurately, as a distinctive and unattractive form of debauchery, oriented around excessive drinking and sexual exploitation of enslaved women and free women of colour. The overwhelming importance of slavery in Jamaica accentuated the trends towards a debauched version of hospitality that stressed white male pleasure over everything else as a central animating value in society.

In the years before the American Revolution, Jamaica was the wealthiest and most unequal colony in the British Empire. Its white residents are the subject of this essay on the peculiar drinking culture developed by the 'British male abroad.' White planters and overseers formed the backbone of Jamaica's supervisory staff on its nearly 700 sugar plantations and numerous smaller plantations. Their great wealth enabled them to live far from abstemious lifestyles. Meanwhile, enslaved people of African origins were among the poorest and worst treated 
populations in the early modern world. ${ }^{1}$ This study of how whites drank and caroused while living in the middle of huge deprivation indicates how the monstrousness of Jamaican slave society can be assessed. Just as importantly, the repeated boasts white Jamaicans made that they were the most hospitable people in the world did not match the sordid reality of how that drinkfuelled hospitality was openly accepting of debauched white behaviour. White Jamaicans developed a drinking culture that drew on British precedents that mutated in the tropics into a form of different sociability from the civility of mid-eighteenth Enlightenment Europe.

Social occasions usually involved lots of hard drinking and dancing, an activity whites found exciting. J.B. Moreton, who along with the much better-known Edward Long is used here to investigate Jamaica's debauched drinking culture, believed that white Jamaicans were so addicted to dancing that if a Creole 'was languishing on his death bed, I believe the sound of a gumbah or violin would induce him to get up and dance till he killed himself.' 2 This dancing, however, was closely allied to sexual exploitation. Depictions of fancy dances such as at the Governor's house in a print entitled 'A Grand Jamaica Ball! Or the Creolean Hop à la Mustee' show white Jamaican ladies, having presumably learned such steps from the free coloured women who attended 'Mulatto Balls' (hence the sly reference to 'mustee' in the title, as if white women had an element of African about them), cavorting in what to European eyes were wildly indecorous ways. They recline ungracefully, drink to excess and dance with arms and legs splayed in unbecoming ways. The satirist argues that these women's failure to uphold proper standards of comportment made them 'charmless. ${ }^{3}$ And he shows in a vignette at the top of the print the ultimate consequence of this loose behaviour: illicit sex. Dancing as prelude to sex was made explicit also by Thomas Thistlewood who confided in his diary that Jamaicans sprinkled 
pepper on dance floors because 'as soon as they begin to warm, it rises and has such an effect upon the women's thighs, \&c that it almost sets them mad and easy to be debauched. ${ }^{4}$

Drink, dancing, and illicit sex combined to create a milieu in which activities frowned on in Britain, or confined to specific and highly regulated homosocial encounters, were central to white male cultural practices. We could concentrate on dancing, or, as is often done, on sex as an entrée into this alternative culture of the behaviour of the British male abroad in the eighteenth and early nineteenth century tropics. ${ }^{5}$ But white male attitudes to drink in Jamaica are an especially capacious way of understanding the development of a tropical male sensibility at odds with a British culture being transformed by evangelicalism (and the abolitionist impulse). The move towards politeness and 'civilised' behaviour was not a linear nor uncontested process in which riotous social practices, including those occasioned by copious drinking, were set aside in favour of more decorous ways of behaving by modern refined men. Societies could be 'modern' without being polite, as is very evident in the debauched behaviour of white men in precociously modern Jamaica. ${ }^{6}$ The model of white Jamaican masculinity was a libertine model - the model increasingly being discarded in Britain as a more modest, religious and family-oriented model took hold in the lead up to the Victorian age. This libertine model, however, was not a hangover from a less civilised past that declined as modernity increased. Rather, it was a distinctive and successful cultural adaptation to the tropical environment which many white men found appealing.

Key to this analysis is that white men lived in, and took pleasure in living in, an enslaved society, in which drink was one of several ways in which white male enjoyment and entitlement was 
demonstrated. The overwhelming importance of slavery in Jamaica accentuated a debauched version of hospitality that stressed white male pleasure as a central animating value in society. Numerous historians have stressed how slavery contributed to changed white manners in Jamaica, their findings enabling a quick sketch of the impact of slavery on sociability. For critics of the West Indies, slavery explained almost every deficiency in the Creole character, from Creole's lack of religion, their innate cruelty, their unconcern with the future and their inconstancy and impetuousness. ${ }^{7}$ John Fothergill made the link explicit in 1765, declaring that Creoles were enabled by slavery to live lives 'of Idleness and Extravagance.' Surrounded by birth by 'dark Attendants, they quickly become 'habituated by Precept and Example, to Sensuality, Selfishness, and Despotism' leading them to pursue 'Splendour, Dress, Shew, Equipage, everything that could create an Opinion of their Importance ... at the Expence of the poor Negroes, who cultivate their Lands. ${ }^{8}$ As Simon Gikandi notes, observers noted that planters seemed incapable of self-control, especially in regulating between the demands of virtue and the opportunities afforded by commerce: 'slave masters often seemed caught between the demands of the new polite culture that had evolved in Europe, one that demanded self-restraint and the management of passions, as well as the materiality of the plantation system, often driven by greed and opulence and manifested in moral disorder.' 9

\section{II}

Let's approach this topic through references to drinking and hospitality in the detailed diaries left by Thomas Thistlewood, a British immigrant who became an overseer and small pen-keeper. His diaries are a remarkably frank examination of life in a Jamaica in which over ninety percent of the population were enslaved people of African descent. ${ }^{10}$ Thistlewood was abstemious by 
Jamaican standards. His accounts of the drunkenness of others shows white Jamaicans' addiction to excess in a society in which people suffered starvation and deprivation. In 1771, aged 50, he was at the height of his powers, a newly appointed magistrate, landowner and an accomplished gardener and scientist. He entertained regularly and profusely. He invited guests to lavish dinners 12 times in 1771 while going out for elaborate dinners even more frequently. Some of these feasts outside his house were official functions, as on 9 April 1771 when at a vestry sitting there was 'ham, beef steaks, broiled king fish, cheese' with lots of punch to drink.

Thistlewood ate so much that he declared that he was unable to eat a meal later in the day. When he entertained others, moreover, he was the consummate host. On 2 January 1771, for example, he entertained eight guests with 'a boiled fowl, with pickled bacon and Greens, a roast turkey cock, Crabs, Watermelon, boiled kidney, beans etc porter, punch, Madeira wine and coffee.' On 17 January 1771, he outdid himself, providing 10 guests with 'roast goose and papah sauce, roast pork and broccoli, roast whistling duck, stewed hogshead, fryed liver, giblet pie, boiled pudding, bread, cheese, grapes, shaddock, watermelon, oranges, madeira wine, porter, grog and brandy.' Some of this porter was his own: he wrote a lengthy account of his efforts making porter on 20 July. At the end of the year he tallied how many animals he had killed for his table, noting that he had killed 13 capons, 20 chickens, 22 young cocks, one turkey cock, 10 squab ducks, 5 geese, 9 pigs and many land turtles.

The eighteenth-century Jamaican historian, Edward Long, saw such munificence as signs of Jamaica's growing sophistication - white men and white women sharing convivial meals and high-quality drinks at a groaning table. ${ }^{11}$ Thistlewood's dinners in 1771 conform to such an 
interpretation. Yet some of these dinners tended more to riot than sophistication. Thistlewood gave a lengthy account in 1776, for example, of a boozy dinner of soldiers where 'the grenadiers treated their officers.' The bill, he noted with amazement, came to over $£ 300$ and the officers got heartily drunk and destroyed furniture and glasses to the value of $£ 60$ and wasted 36 bottles of claret at 15 shillings per bottle. The drunk soldiers had many quarrels but were satisfied with the result. Indeed, Thistlewood estimated that as there were 60 men at the banquet, the damage came to a manageable $£ 5$ each. ${ }^{12}$

Excessive drinking did not always have such positive consequences. Thistlewood related on 19 November 1776 how Mr. Fisher 'was in Liquor, as he almost continually is' and accidently shot a member of the light infantry. But whites did not suffer much from drunken excesses; the brunt of the suffering was born by enslaved people, especially enslaved women. Thistlewood noted several occasions where white Jamaicans followed up extensive sessions of drinking by raping enslaved women. On 21 August 1756, Thistlewood wrote that 'the white driver [the newly hired] William Nugent was beastly drunk and wanted to force Rose.' Thistlewood dismissed Nugent 'for his bad behaviour.' He was forced, however, to accept the misbehaviour of his peers, such as Samuel Say and Stephen Parkinson, who on 26 December 1760 raped slave women. Thistlewood was especially powerless when his employer, John Cope, who frequently pursued enslaved women when drunk, raped slave women, as on 16 November 1756 when after dining out and being 'in Liquor,' he 'went to the Negroe house and had Little Lydde in Jennys' house.' The most notorious incidence of drink-fuelled sexual violence was on 2 May 1760 when Cope and Mr. McDonald 'sat drinking for some time' and then each raped a slave woman - McDonald with Eve and Cope with Beck, 'with whom he was till morning.' The next day Thistlewood also 
had sex with Eve and watched Cope order the whipping of two women who had refused him before he ended up with Beck. Slaves usually put up with such indignities but in this case, they were so outraged that they informed Cope's wife what Cope had been up to, leading to an almighty row, in which Cope's belongings were smashed by his wife.

White Jamaicans connected to each other through this socially divisive drinking culture. We need to remember that it was more than a shared interest in debauchery that brought white men together and that 'debauchery' was only a symptom of wider societal cultural dysfunction. Jamaica was an economic powerhouse based on the production of sugar and other tropical crops, as well as having a substantial trade with Spanish America. That economic dynamism was predicated upon the relentless exploitation of enslaved people in a society that Orlando Patterson contends was characterised by especially weak institutions. One advantage of this weak institutional structure, Patterson contends, drawing off my work in earlier contexts, is that white immigrants flocked to Jamaica not just for the chance to get rich in a system in which the interests of enslaved people were constantly relegated in importance, but for the strong possibilities of enjoying the sexual exploitation of enslaved women and the perverse pleasure of dominating black male slaves. ${ }^{13}$

Patterson argues further that slaves existed in a world of uncertainty where the enslaved were always vulnerable to repeated depredations that led to 'significant slave dehumanization as masters sought, with considerable success, to obliterate slaves' personal histories.' Patterson terms Jamaica as a Hobbesian society, in which planters inflicted upon slaves 'a reign of terror' and 'a holocaust' in an 'uniquely catastrophic' slave system in which out of control whites 
operated with 'near genocidal cruelty.' He emphasizes that slavery was chaotic because white life was also chaotic, with white Jamaicans 'screwing themselves stupid ... smoking too much ... drinking too much. ${ }^{14}$

Drink made the cruelty of whites towards blacks transparent, uniting whites in a shared understanding that white drunkenness could always be excused. We can see this unity in a conflict recorded in Thistlewood's diaries on 20 March 1753. He was roused outside from his meal to deal with two men - Paul Stevens and Thomas Adams - who were 'both drunk' and who 'were going to tear Old Sarah to pieces (Old Sarah was later recorded as dying on 16 August 1771, eighteen years after this event). He 'had a quarrel with them.' But Thistlewood had no hard feelings. On 10 July 1753, Thomas Adams came by in 'his Troop dress' and 'asked pardon for his ill-language he gave one night by Sarah's gate, with Mr. Paul Stevens, both being almost drunk.' Thistlewood accepted his apology and 'we parted good friends.' The apology, it should be emphasized, was for the injury done to Thistlewood. There was no mention that the two men were sexual predators thwarted in their ambition to rape a woman, probably a woman in her $40 \mathrm{~s}$ or 50s, thought of as 'old.'

Old Sarah may have not been so forgiving. She narrowly escaped being raped by two drunken soldiers. Of course, such events happened in Britain as well. Drink fuelled violence was hardly confined to Jamaica. But the culture of Jamaica - hard-drinking whites who drove their slaves relentlessly and who always sought to indulge their desires - added a new dimension of 
harshness to incredibly difficult enslaved lives. Slaves took the brunt of the bad behaviour of drunken Englishmen in the tropics.

III

White Jamaicans were hospitable, but they were not polite. Indeed, terms that were used to characterise Jamaican behaviour and attitudes tended towards the antonyms of politeness debauchery, degeneracy and libertinism. For patriotic white Jamaicans who were offended by the many aspersions that metropolitan critics made about their character, the answers they gave why white Jamaicans acted in appalling and ill-disciplined ways revolved around climate, the malign influence of living in societies full of Africans, the failure of white women to civilize white men away from their inflamed passions, and shameful indifference to religious attendance and religious tenets. They argued that such behaviours were retrogressive throwbacks to a less cultured time, when the exigencies of settling a colony encouraged uncivilised behaviour. Jamaica was moving, in this scenario, through its culture of hospitality into greater conformity with established modes of behaviour in Britain. It was leaving the gross excesses of the past behind. ${ }^{15}$

My argument does not conform to Norbert Elias' theory about the civilizing effect of manners over time. ${ }^{16}$ White Jamaicans, especially men living on plantations, were not moving towards a culture of politeness underwritten by sociability. Instead, they developed cultural forms in which hospitality was a paramount virtue but in which the leavening qualities of gentility as evident in much of Anglo-American society such as increasing self-control, lessening displays of rage and aggression and increasing adherence to what might be thought of as bourgeois values were conspicuously absent. Their cultural leanings - what Doris Garraway usefully defines as 
'libertinism' in a study of a similar kind of society developing in eighteenth-century SaintDomingue - were a challenge to European norms about what a civilized society should be. ${ }^{17}$ Order and civilization were increasingly linked in bourgeois Western thought. The modern civilized personality developed from the slow elaboration of rules about conduct that emphasised emotional self-restraint. Violence, excess and lack of restraint showed backwardness. ${ }^{18}$ Thus, it became easy to see slavery - the bulwark of Jamaican social order - as emblematic of antimodernity and the slave owners who inflicted violence on enslaved people as regressive personality types whose evils needed to be counteracted through humanitarian reform. ${ }^{19}$

Yet much as European abolitionists horrified at planter excess wanted to deny it, the plantation machine in Jamaica and the people who ran it were not antithetical to modernity. The Jamaican planter and merchant class created a flexible and advanced economic system in which modern management techniques were allied to an entrepreneurial and libertarian ethos that appealed to the gentlemanly capitalists moving Britain into a new imperial age. ${ }^{20}$ In their indifference to religion and to inherited status, in their obsession with commodifying almost everything and in their devotion to embracing risk and short-term advantages over long term planning, Jamaican planters and merchants embodied a cultural outlook that was progressive, even if morally vacuous. That culture was marked by white Jamaicans' devotion to profit, their antagonism to established European values such as politeness, their exuberant embrace of hedonism and libertinism, and their continual countenancing of violence as a strategy of control. In short, planters anticipated the values and visions of industrial modernity while rejecting the associated values of bourgeois respectability that eventually turned into Victorianism. They did so with enthusiasm. As Sarah Yeh notes, the 'relaxed morality and the excesses of colonial life might 
have been a welcome relief to settlers who chafed against religious intolerance, social rigidity or the restriction of polite British culture.' ${ }^{21}$

What white Jamaicans did, therefore, in their recalibrations of their cultural responses to their social and physical environment in the late eighteenth century was something new in imperial life. As Louis Nelson astutely notes, planters began to embrace their circumstances rather than fitting their environment into British patterns that did not work for them. In doing so, he argues, 'they formulated a material and social life that stood in stark contrast to the refinement that defined the broader British world.' It might be, as Nelson suggests, that planters 'divorced from British America and socially and culturally assaulted from the British mainland' either threw in the towel by moving from the islands to Britain or else finally abandoned ideas that they were Britons who were just inconveniently away from home. ${ }^{22}$ Alternatively, as an older scholarship suggests, white Jamaicans adopted a creole culture that fused in interesting ways British, African and local characteristics. ${ }^{23}$ In either way, white Jamaicans pioneered a distinctively imperial and libertine form of cultural orientation, often to the horror of Britons who found what their countrymen did when they went to the tropics abhorrent and un-British. This orientation partook of elements of what critics now call 'orientalism' but which also took aspects of metropolitan culture like libertinism and excessive drinking and married them to a belief that life could be lived differently and more freely in the imperial tropics, like the West Indies, Africa, India and the Pacific. Central to this tropical mentality was the idea that the tropics was the 'other' to the western norm: things could be done differently there. ${ }^{24}$ The culture of drink that was exhibited by white Jamaicans was one manifestation of a form of hospitability not aligned to politeness but instead which welcomed a tropical form of excess for the British male abroad. 
IV

The peculiar racial and social structure of eighteenth-century Jamaica bred a remarkably radical egalitarianism among ordinary white men. As the historian Bryan Edwards argued, there was 'a marked and predominant character to all the white residents' in which they demonstrated 'an independent spirit and a conspicuous display of conscious equality throughout all ranks and conditions.' Edwards contrasted how whites in Jamaica acted towards their superiors with social interactions in Europe where 'men in the lower orders of life' seldom considered themselves to be 'nearly on a level with the richest.' In Jamaica, by contrast, 'the poorest white person ... approaches his employer with an extended hand.' As Edwards continued, this white egalitarianism was a function of the ubiquity of slavery in Jamaica and the demographic disproportion between the small white population and the large enslaved majority. Edwards argued that 'so long therefore as freedom shall be enjoyed exclusively by one race of people, and slavery be the condition of another, contempt and degradation will attach to the colour by which condition is generally recognised.' White egalitarianism had a notable effect on the character of white dealings with each other, even to the extent of changing personality. Poor white men did not cringe or creep when encountering rich men. As Richard Renny wrote in 1807, white Jamaicans' 'high spirit of independence' was apparent in their very appearance. Speaking 'what they think, without fear or reserve,' Renny argued that white Jamaicans showed in their demeanour to each other 'no tremulousness of voice, no cringing tone of submission, no disgraceful flexibility of body [and] no unqualified humbleness of countenance. ${ }^{25}$

This radical egalitarianism was a logical outcome of Jamaica's social circumstances, in which white society was dominated by recently arrived white immigrants who suffered from such 
dreadful demographic prospects that their numbers were always being reduced. These demographic realities made ordinary white men a scarce commodity in an economy which needed them to be involved in managing slaves on plantations. White women were few and constraints on white male behaviour were limited. Most important, whites were equally dependent on each other for protection from their slaves. They were equal because the great majority of white men shared a common experience as masters of enslaved people. In short, as I have written previously, the political and social atmosphere of Jamaica in the second half of the eighteenth century 'exhibited a complex and combustible blend of ostensible equality and demonstrable elements of social deference and hierarchy, all predicated on a fierce and allencompassing commitment to chattel slavery.' A white man was thus an egalitarian tyrant, 'determined to defend his own liberties while trampling on the freedoms of blacks. ${ }^{26}$ Drink played a considerable role in this radical egalitarianism.

Jamaica's radical egalitarianism was underpinned by the importance that white Jamaicans placed upon hospitality. White people of whatever social standing could rely on being treated to food, drink, accommodation, occasionally access to horses for travel, and to black women for sexual pleasure whenever they demanded it at the houses of white colonists. Every commentator noted that whites were famed for their open dispositions, their generosity and their eagerness to entertain at a moment's notice. As early as the 1740s, James Knight commended white Jamaicans for their hospitality, asserting that 'there is not more Hospitality, nor a more generous Freedom shown to Strangers in any Part of the World, for any Person who appears like a Gentleman and behaves himself Well, is Sure of a Welcome to their Houses and the best 
Entertainment they can Afford ... [while] Persons of low rank and Condition are as cheerfully received and entertained by their Servants. ${ }^{27}$ J.B. Moreton, who wrote a manual on Jamaican society for aspiring clerks and slave overseers, claimed that it 'was quite customary for travelling people to call on each other, though strangers, for refreshment for themselves, servants, and horses, and that too without any ceremony or formality. ${ }^{28}$

The custom of hospitality was bounded by gender and especially by race. As Christer Petley notes, acts of hospitality were generally acts of male bonding, focused around excessive drinking, eating and wenching. ${ }^{29}$ The few white women who lived in the island tended to be excluded from most male gatherings and often themselves did not attend events if they risked encountering the mixed-race mistresses of white men. Maria Nugent, the wife of an early nineteenth-century governor, whose journal provides a wonderful insight into the mores of Jamaican society on the eve of the abolition of the slave trade, noted from the start of her arrival the absence of women from many social gatherings and the casual gender segregation everywhere apparent. It was one of her principal bugbears in her time in Jamaica that she could not find suitable female companionship and that white Jamaicans had not adopted the gendered fashions of dining in Britain where families ate together at mealtimes, where wives were mistresses of the house, and where men and women sat alternately at seats around the dining table. $^{30}$

Race was a far more fundamental divide. Slaves were excluded entirely from white cults of hospitality except in often awkward carnivalesque inversions of social order such as the nineteenth-century African-Jamaican festival of Jonkonnu. ${ }^{31}$ Free people of colour were also 
normally left out of white gatherings even though interracial relationships were so common that every 'unmarried white man and of every class, has his black and brown mistress with whom he lives openly.' Some commentators noted that white women might visit the house of a so-called Jamaican bachelor and 'partake of his hospitality, fondle his children, and converse with his housekeeper.' But generally, their mixed-race mistresses withdrew when strangers, especially white women, were present and dined separately. And even though it was an open secret that white men kept mistresses they tended not to parade their mistress in public spaces, as that was likely to harm their reputation. ${ }^{32}$

This cult of hospitality was as peculiar as the society that sustained it. It was connected to currents of sociability that were a marked feature of Anglo-American life in Britain and in British North America. But it was not the same sort of sociability as in these places. Sociability in Anglo-America was ineluctably linked with politeness, which itself can sometimes seem so idiomatic to the eighteenth century that it can be just a slightly vacuous means of referring to a mass of related changes in middle-class behaviour and values that eventually were overturned by the move to Romanticism in the nineteenth century. ${ }^{33}$ Jamaican hospitality, however, never led into politeness or into modes of behaviour characterised by terms like 'civility' or 'gentility' or marked by any sort of decorum in behaviour or personal style. ${ }^{34}$

\section{V}

Jamaicans lived active social lives, careening about in kitterines (carriages), according to Moreton, instead of going to church. They were obsessed by dancing and continually indulged in bouts of competitive eating and drinking at communal dinners, either at private houses or after court sessions or military musters. In the countryside, they spent evenings 'in conversation, 
smoking and drinking' where they proved 'bon vivants' with 'even the lowest tradesman drinking wine after dinner, besides rum, or brandy or water in the afternoon. ${ }^{35}$ Thistlewood entertained or was entertained constantly. In the first half of 1775 , for example, he dined out or invited friends to his house on 73 occasions. On these occasions, they feasted on roast beef, seafood, cassava, sweet potatoes, various rich sauces and seasoning and fruit accompanied by 'French Brandy ... punch and porter.' Some of these foods were British in origin but many more were derived from Jamaican experience and some, like pepper-pot soup and tum-tum, were of African derivation. ${ }^{36}$

The problem with their eating and drinking was that little of it was done in moderation. Excess was the theme that commentators harped on about when discussing Jamaican eating, drinking and gambling habits. The priggish and abstemious Lady Nugent tartly declared that white Jamaican men 'ate like cormorants and drank like porpoises' When she visited the 'very vulgar, yet humane' planter, William Mitchell, she noted that his main aim seemed to be 'to stuff his guests.' Nugent commented that 'I should think it would be quite a triumph for him, to hear of a fever or apoplexy, in consequence of his good cheer.' Mitchell piled his tables high with 'loads of all sorts of high, rich and seasoned things, and really gallons of wine and mixed liquors as they drink!' It was all, she concluded, 'as astonishing as it was disgusting.' The meals at the house of another Jamaican grandee, Simon Taylor, were just as offensive to Nugent being 'so profuse' that she felt compelled to list all the foods and drinks in detail, before admitting that she felt 'sicker than usual, at seeing such a profusion of eatables.' She was no more impressed by Jamaican table manners, noting that at one party everyone, including boys of fifteen or sixteen, were drunk and that everyone 'spoke with his mouth full. ${ }^{37}$ 
Of course, Nugent was a governor's wife and people pulled out all the stops when such dignitaries visited. Taylor mentioned to Nugent after her visit that 'he must go home, and be abstemious, after so much feasting. ${ }^{38}$ But overeating and excessive drinking were common in everyday life. Moreton, always up for a racy phrase, lamented that Jamaicans 'in general drink to excess ... [and] wreck and train their constitutions.' 'Grog drinking and smoking segars,' he lectured his readers, 'is a baneful and obnoxious practice' with gluttony another 'kindred vice. ${ }^{391}$ Robert Dallas neatly summarised all the vices that residents of Jamaica were prone too thus: 'An Englishman, in the torrid zone, loving a greasy old black woman, indulging his gross appetites, a gentleman, a companion in request, self-approving, eating, drinking, sleeping away his life in solid and substantial happiness. ${ }^{40}$

What made these gross perversions more glaring was the sharp contrast between the plenty of the planter's table and the starved condition of enslaved people. Slaves lived at the edge of subsistence and often got very close to famine. Even in good times, enslaved people had an 'uncertain and limited command of subsistence. ${ }^{41}$ In the hurricane-tormented years of the 1780s, slaves faced starvation. Hector McNeill recalled in 1788 how following the great hurricane of October 1780, he had been horrified by 'the misery of beholding hundreds of wretched beings around you, clamouring for food and imploring that assistance which you cannot bestow.' The Assembly of Jamaica declared in 1780 that 'the sufferings of the poor negroes ... were extreme.' Yet famine was a constant, rather than an exception, in the lives of Jamaican slaves. The relentless plantation regime, in which enslaved people had to work and feed themselves, kept many enslaved persons, such as the sick, the old or those with large families, on the edge of 
destitution and constant hunger. ${ }^{42}$ The contrast between starving slaves and over-consuming whites was stark. The one time when enslaved people ate well, and, just as importantly, got to drink and get drunk was at Christmas, when planters gave their workers 'treats,' including portions of rum, distributed according to status, with men getting more than women and drivers and skilled slaves more than field hands. The Christmas season, consequently, was the most dangerous time of year for slave owners as it was the time when rebellion was most likely. It is likely that enslaved people were able to contemplate rebellion at the time because they had full bellies and were perhaps emboldened by drink - it was the one time of the year when food and drink were enough for enslaved people to have the energy to do more than merely survive. ${ }^{43}$

White consumption was highly visible in a society where most people did not get enough to eat. Every social occasion for white men involved eating and often hard drinking. For example, after militia reviews, men removed to taverns or great houses to fill their stomachs with drink and food. Elections were other venues of open public over-consumption. As Christer Petley comments, 'the 'loyal toasts' after election days, drunken homosocial private gatherings, and lavish second breakfasts that followed morning militia reviews, all reflected the importance of male bonding and white entitlement in a land of slavery. ${ }^{44}$ Metropolitan observers noted this excess and did so disapprovingly. White Jamaicans' lack of self-control in their pursuit of pleasure - either of the table, in the tavern, on the dancefloor or in the bedroom - all suggested a problematic people who in their unrestrained nature and their hypochondriac tendency to become invalids indicated a deep malaise in the Creole white character. ${ }^{45}$ 
VI

The most sophisticated exploration of hospitality in Jamaica was undertaken by Edward Long in his ambitious historical sociology of Jamaica written in $1774 .{ }^{46}$ Long covered a vast range of topics in his often-digressive text and was not always internally consistent but one of his principal themes was that Jamaica was not just a productive place valuable to the empire but was a rapidly improving colony that was increasingly meeting metropolitan standards of public morality and behaviour. Long often criticised Jamaica, notably condemning white Creole men's devotion to heedless hedonism and their incessant short-termism addiction to immediate fixes rather than long-term planning. Nevertheless, Long argued that planters had a host of attractive characteristics, including being notorious for their abundant hospitality to friends and strangers alike and their devotion to 'gaiety and diversions.' He noted their faults, as well, though he tended to describe such faults like indulgence, sexual excess and conspicuous consumption as framed within the context of Jamaica's cult of hospitality. In their compulsive hospitality, he concluded 'there are no people in this world that exceed the gentlemen of this island in noble and disinterested munificence.' Jamaicans' hospitality was 'so unstinted,' he argued, that 'no men, nor orders of men, in Great Britain, are possessed of more disinterested charity, philanthropy, and clemency than the Creole gentlemen of this island.' They loved excess, especially regarding food and drink, and were unconcerned with limiting their generosity according to the status of the white people they entertained. He noted that Jamaicans 'have lodging and entertainment always at the service of transient strangers and travellers.' These travellers received much attention: 'their tables are covered with plenty of good cheer, and they pique themselves on regaling their guests with a profusion of viands. ${ }^{47}$ 
Whereas Long insisted that Jamaica was improving, becoming more Anglicised and shedding its more disagreeable features so that eventually it would contain a people who evoked civilised values at every turn, a quite different picture of West Indian hospitality and Jamaican manners emerged in J.B. Moreton's racy guide to West Indian customs. Moreton's book was far less ambitious than Long's great work, being a romp over Jamaican life designed to describe life in Jamaican to immigrant overseers he derisively and offensively called 'cowskin heroes' in honour of their attachment to their whips as a means of disciplining enslaved people. At the end of the book he reversed tack and delivered a series of unconvincing platitudes about the need to follow conventional morality. But before those bromides, his book celebrated the dubious morality that characterised white life in the island. Indeed, his book was a subversive tract, ostensibly paying lip service to ideas of moral improvement while highlighting and recommending Jamaica as a place where whites could practise unbridled hedonism. ${ }^{48}$

For Moreton, Jamaica was a land devoted to pleasure. He assured readers that Jamaica was full of people devoted to fun and that the island was an egalitarian paradise where 'all marks and denominations of people are more friendly, kindly and hospitable than in milder climes. ${ }^{1} \mathrm{He}$ purported to find white Jamaicans' fondness for over-drinking and gluttony sinful but the ways in which he described these practices suggested his heart was not in the condemnation. It was more in the celebration of Jamaican love of pleasure. Gambling was another sin he pretended to believe was appalling - 'it is impossible for men who are fond of gambling to be honest, thus consequently they must be rogues. ${ }^{49}$ But he was not being honest in this condemnation, as subsequent comments showed. Gambling, he thought, made everyone equal. In Jamaica, gambling was 'practised to a great and ridiculous extreme' but had some value as a means of 
levelling social distinctions because 'at a gaming table all people are on a footing without any distinctions of persons.' 'There,' he contended in a vicious anti-Semitic comment, 'the nobleman divests himself of all honour, and levels with the vilest swinge buckler, there the Christmurdering Shylock has as much influence as the brave general or violent admiral. ${ }^{50}$

Moreton laid bare in his frank discussion of the lure of illicit sex for incoming migrants the reality behind Long's lament that white men were easily seduced by sexually avaricious black women. White men in Jamaica, Moreton showed, were not ardent lovers unable to resist their impulses in a climate that encouraged lack of restraint. They were sexual predators who saw nonwhite women as sexual targets, justifying their predations with rationalisations that African women were sexually insatiable. White Jamaicans' much vaunted cult of hospitality was often a cover for tawdry sexual opportunism. It was 'quite usual,' he asserted, for a Creole gentleman 'after dinner to send to the field for one of his favourite wenches, who is instantly hurried home and conveyed to his chamber.' 'Thus,' he continued, 'he takes one almost daily in rotation and roves with as much ease and dignity as a plenipotentiary through raptures of delight, and enjoys happiness as he likes it. ${ }^{\text {51 }}$ The emphasis here is on white men 'taking' sexual license frequently, openly and without worrying about consent. Social occasions were less occasions of conspicuous hospitality than sordid drunken debauches, in which the ultimate object was the sexual exploitation of black women. ${ }^{52}$

VI

The peculiar demography of white society in Jamaica and of life in the 'torrid zone' where excessive mortality meant that marriages were short, children were in short supply, and the likelihood of early death was very high, giving an identifiable tropical tone to Jamaican 
sociability. The hospitality of whites was that of young men in a society where there were few older men and even fewer white women who could provide a check on their proclivities. Not surprisingly, young immigrant men without familial constraints doing stressful jobs controlling resentful and occasionally dangerous slaves gave vent to their passions and ate too much, drank to excess and indulged their sexual appetites. These appetites were whetted by accounts such as that written by Moreton, which pictured Jamaica as a land of sexual opportunity and unrestrained debauchery. Long and Moreton stressed in different ways the attractiveness of Jamaica as a site for white male enjoyment. Long was concerned with how Jamaican values cohered with the admirable virtues of the British people. Moreton was interested in catering to the pleasure principle and to the individual benefits white immigrants obtained from living in Jamaica. His view was both tawdrier and probably more accurate than Long's paean to the essential goodness of the white male character.

Long was the greater historian, of course, but his explication of the white male Jamaican personality involved a large measure of self-delusion, as seen in his contention that Jamaicans were humane masters and in his resolute refusal to accept that Jamaica was an unhealthy place where white mortality was so excessive that natural population increase was impossible without very large migration levels. Other observers were not so sanguine about Jamaica's future prospects. The Reverend William Jones spent a brief but unhappy time in Jamaica in 1778 and was appalled by what he saw of ordinary white male behaviour. He thought that the 'real History of plantation-vassalage' saw the youths who came from England to gain a fortune become 'barbarous... devil incarnates' who became torturers for the pleasure of hearing 'the groans and cries of negroes' and then engaged in 'drunkenness and debauchery.' 'The life of this refuse of 
mankind,' he thundered, 'is no other than a continued Scene of Ignorance, Profaneness, Cruelty, Drunkenness, unbridled Debauchery, \& whatever, if there be anything else that may disgrace the nature of brutes. ${ }^{53}$

Of course, the 'drunkenness and debauchery' that so offended Jones was not something unknown in British male culture. Libertine culture was a feature of elite sociability in Georgian Britain, though, as noted above, the move to what Boyd Hilton calls 'the age of atonement' in the second quarter of the nineteenth century meant that increasingly libertinism was ideologically and politically suspect. ${ }^{54}$ Moreover, it is hardly unusual for a clergyman to be against sinful behaviour. In Georgian Britain, even when moralists affected to be shocked by outrageous male behaviour undertaken by rakes, highwaymen or pirates the things that these reprobates did tended to be glorified through the very fact of having them condemned as ungentlemanly. Against a culture of politeness in the eighteenth century was counter-posed a much racier culture in which traditional expressions of male behaviour like that common in Jamaica were celebrated. Gambling, whoring, over-consumption and excessive drinking were central to certain kinds of male identity in Regency Britain just as much as they had been in Restoration England. Charles Fox and Lord Byron were widely admired despite or perhaps because of their moral derelictions. ${ }^{55}$ And advocates of moral reform like William Pitt, Jr. and especially the abolitionist leader, William Wilberforce, were mocked for their priggishness and, in Pitt's case, for his lack of sexual activity with women and for his seeming effeminacy. ${ }^{56}$

In short, as Judith S. Lewis has argued when looking at gender politics in the late eighteenth century there were two models of masculinity in contention in Georgian Britain, which in British 
politics conveniently were personified in the debauched but fascinating Charles Fox against the workaholic ascetic William Pitt, Jr. One model, Lewis suggests, was performed in hard drinking, womanizing and sport while the other model emphasised austerity and independence from sexual appetite - or at least sexual appetite outside marriage (the ideal English gentleman in this scheme could be fecund, but only within marriage) ${ }^{57}$ The battle was fierce, but the victor was clear: it was the model of masculinity advanced by Pitt, George III and Wilberforce that prevailed, leading eventually to the repressive Victorian age. ${ }^{58}$ The battle, of course, was not won completely. Libertinism did not disappear but tended to be more circumscribed and put within clear, and highly gendered, boundaries. Kate Davison makes a case for what she calls 'occasional politeness' in eighteenth-century male society. She stresses that polite prudence could be waived and looser manners encouraged when men, especially elite men, met in friendly homosocial encounters. ${ }^{59}$ The point, however, is that in late eighteenth and early nineteenth century Britain, the kind of behaviour done openly and without social opprobrium by white Jamaican men in tropical settings was relegated to confined spaces and to clearly defined social occasions which were thought of as being separate from, rather than being a constituent part, of normal social relations.

Moreover, the model of masculinity that won out in this contest of masculine styles operated in tandem with changing patterns of elite female sociability. As Lewis, Marilyn Morris and Elaine Chalus have argued, women in Britain had a growing presence in the public sphere as well as increased influence, in an increasingly important domestic sphere. ${ }^{60}$ In Jamaica, women had no such importance in either the public or private spheres. And, as I have argued elsewhere, white Jamaicans, as the cartoon villains in the developing abolitionist campaign of the 1780s, were 
depicted as being the kind of men that men and women who rejected traditional models of assertive masculinity found most appalling. ${ }^{61}$

The dynamics of developing models of masculinity within cultures of politeness and respectability which marked out late eighteenth century shifts in public and private culture played out differently, however, for British males overseas. Increasingly, there was a gap in what white men overseas felt they could do and how their actions were viewed at home. This gap in perception about the boundaries of acceptable behaviour in the tropics led to scandals by the 1780s, when a metropolitan population became both increasingly disturbed by what was being done by white adventurers in the Caribbean and in India in its name and horrified by the loose morals and errant sexuality of nabobs and planters, either in the empire or, worse, at home.

Drink played a part in this turning against the tropics. The levels of drunkenness in the tropics was of a different order to those in Britain and had deleterious effects on white health. That white residents of Jamaica were debilitated by alcoholic and sexual excess became a standard trope in the description of West Indians in the $1780 \mathrm{~s} .{ }^{62}$ But perhaps of more moment was the ways in which excessive drinking affected Britain's military capacity, especially as it embarked on major campaigns against the French within the Caribbean basin during the French Revolutionary and Napoleonic wars. Troops sent to the Caribbean died in massive numbers from disease rather than from warfare. The common understanding of why this happened is that ordinary soldiers were addicted to 'venery' and even more to drunkenness. It was intemperance that was harming Britain's geopolitical interests by destroying the masculine hardiness of its soldiers and sailors both groups being addicted, it seemed, to rum drinking. ${ }^{63}$ 
Such behaviour, though shocking to prigs and social conservatives at home, might be thought by some men as attractive, especially to the type of men who were the target audience for Moreton's racy anecdotes about white male pleasure in Jamaica. Increasingly, planters responded to metropolitan criticism not by denying attacks on their behaviour as unwarranted or by excusing such behaviour as a natural consequence of life among slaves but by arguing that the peculiar culture they had created was a rational, sensible and desirable response to modernity in the plantation system. Sarah Yeh perceptively notes that West Indian planters were 'a disturbingly extreme version of the new 'improving' landlords in rural Britain who callously hired and fired tenants and laborers according to their needs without any sense of obligation or responsibility to those beneath them. ${ }^{64}$ They also seemed to be prone to moral delinquency, not just in Jamaica but in Britain, where they were often involved in upper class sexual scandals. Both the immensely rich Beckford family and the equally wealthy Tharp family were highlighted in the popular press as examples of Caribbean depravity ${ }^{65}$ Yet that was just one view and not one necessarily held by all Britons, especially among the modernising, improving landlords that other Britons found disturbing. Jamaican planters were often admired for their relentlessly modern management strategies. Christer Petley's sensitive biography of the most successful planter in late eighteenth and early nineteenth century Jamaica, Simon Taylor (1740-1813), shows that Jamaican planters could be at the forefront of modern agricultural practices while eschewing any pretension to paternal concern for enslaved people or needing to adhere to European codes of polite sociability ${ }^{66}$ West Indian whites had their defenders as well as their detractors. ${ }^{67}$ 


\section{VII}

In many ways, 'drugs were at the heart of empires.' ${ }^{68}$ So too was drink. It bound some people together and excluded others. It also separated out one part of the empire - the respectable part, located in the temperate regions of North America and later Australasia, as well as Britain itself - from another - the tropical empire, where white men customarily behaved outrageously. In the respectable part of empire, as David Hancock has meticulously documented, drink, especially wine and even more so madeira became a marker of class difference and social decorum. Drink was mainly consumed at home, involved expensive accoutrements, not inconsiderable skill, and could be easily equated with hospitality rituals and with refinement and gentility. Significantly, drinking wine brought both sexes together in shared acts of sociability that showed the increasing Anglicisation of colonial elites. ${ }^{69}$

Decorous drinking was not a feature of life in the West Indies. Indeed, as is revealed in a large oil painting entitled Sea Captains Carousing in Surinam (circa. 1755-1769), the West Indies was a place outside normal constraints, where drinking led to debauchery. Painted by John Greenwood, the painting describes an imaginary event where New England sea captains, all members of a Newport drinking club, were pictured as being gathered together 'on a spree' in Surinam, despite not all being there at the same time. That Surinam was chosen as the place where these friends might gather is revealing. The West Indies was a place where drinking to excess was expected and where masculinity was expressed in drunkenness. The captains are portrayed in various states of debauchery, one vomiting, one dancing madly and several in states of severe inebriation. The only blacks are a diminutive barely clothed male waiter and a halfnaked female 
barmaid. Two men are shown departing, going either to bed or perhaps to other forms of riotous behaviour. $^{70}$

It was a scene that pictured debauchery and degeneration that was typical of white male social life in the tropics. It also reflected a growing feeling in Britain and British North America that the British tropical empire corrupted British bodies and souls through an excess of luxury and nervous stimulation, made worse by over-drinking. The tropics were places where the European body became enervated and Europeans became invalids through excessive 'venery' and overconsumption of food and drink. Jamaica was a place of racial decline, characterised by a deterioration in manly vigour and diminishing martial prowess, as seen in alarming mortality rates among soldiers and sailors. The dangers of the tropics were manifested in ill-health and drunkenness. And it seemed to some observers that these tropical characteristics were migrating to the metropolis and being absorbed by the growing urban working class whose pathogenic habits, John Bewell asserts, were increasingly equated with Britain's colonial subjects. ${ }^{71}$

Indeed, the figure of the Creole in metropolitan discourse was a disturbing figure that played at British anxieties about moving people raised in temperate zones to the tropics. ${ }^{72}$ Their `disturbing capacity for shape-shifting' undermined a cohesive sense of English nationhood abroad, suggesting as Carolyn Vellenga Berman puts it, that 'Englishness itself is disconnected or dis-composed by its Creole shadow. ${ }^{73}$ It was crucial, therefore, that the increasingly denigrated white Creole body- seen as diseased, tyrannical, cartoonishly idle and slobbish- was considered formed solely in the tropics but British writers had their doubts about whether such bodies could be so physically confined to tropical areas. As Emily Senior argues, 'while physical 
disease is located in the body of the white Creole and tied to the Caribbean islands, the source of the moral corruption is undoubtedly Britain. ${ }^{74}$ It was worrying that British immigrants to Jamaica copied Creole habits, turning healthy British bodies into diseased Creole ones, thus showing the malign effects of the tropics on character and physiognomy.

A propensity for hard drinking (at least among white men: white men were thought of as permanently intoxicated while white women, reputed to abstain from alcohol, were injuring their health by dangerous sobriety) permeated images of the perils of living in tropical climes in Jamaica. A cartoon strip from 1800, 'Johnny Newcome in Jamaica,' portrays a recently arrived immigrant who quickly dies from yellow fever but in a brief period when seemingly recovered from illness thinks himself 'seasoned' and thus 'creolises' himself by smoking a cigar so as to 'puff sickness away.' Significantly, this strip of the cartoon shows Johnny with his feet up on a table of empty glasses, suggesting that acclimatization to Jamaica meant becoming constantly drunk. An even more pointed pictorial summary of the links between drinking, disease and death, is in 'The Torrid Zone. Or Blessings of Jamaica' by Abraham James, from 1803. James connects disease, tropical languor, sloth, smoking and drinking in a rich and complicated aquatint in which white Jamaicans sat unwittingly on top of an inferno of yellow fever while a hideous angel drunkenly oversees the lounging and self-indulgent white Jamaicans with a bottle of rum pointedly in hand. It makes an indelible association between disease, drink, licentiousness, and greed in the making of the white Jamaican. ${ }^{75}$

Ideas about the tropics formed in the Caribbean quickly migrated to other tropical regions, notably India. As in Jamaica, Anglo-Indians drank prodigiously and had dramatically low life 
expectancies, a coincidence that contemporaries did not think was accidental. ${ }^{76}$ And, as in Jamaica, planters were especially notorious for how much they drank, and how their drinking was associated with physical and sexual violence toward their Indian workers. ${ }^{77}$ Nevertheless, replicating what had happened in Jamaica, drink seemed to be particularly problematic for ordinary white men - 'white subalterns' involved in the control of slaves or native Indians - or for soldiers stationed in tropical regions. ${ }^{78}$ The excessive drinking culture of the lower classes of Europeans in India, as also in Jamaica, provoked a considerable amount of soul searching in metropolitan Britain, where imperial excesses were an increasing concern. The drunken debauches of British whites overseas were 'a very public demonstration that British rule was not inevitably linked with 'moral progress', ${ }^{79}$ In short, the tropical male abroad was a white drunkard and a sexual predator whose activities undermined the moral purpose of empire in multiple ways. ${ }^{80}$

* This article forms part of Intoxicants and Early Modern European Globalisation: Spaces, Practices, Material Culture, a volume resulting from a workshops series, held in 2015 at the Victoria and Albert Museum, funded by the ESRC 'Intoxicants \& Early Modernity Project', and in 2016 at the Beinecke Library, Yale University. Address for correspondence: Trevor Burnard, Director, Wilberforce Institute for the Study of Slavery and Emancipation, University of Hull, 27 High St, Hull, HU1 1NE UNITED KINGDOM. Email: T.G.Burnard@hull.ac.uk

1 Trevor Burnard, Laura Panza and Jeffrey Williamson, Living costs, real incomes and inequality in colonial Jamaica,' Explorations in Economic History 71 (2019), pp. 55-71

2 J.B. Moreton, West India customs and manners ... (London, 1793), p. 105. 
3 Louis P. Nelson, Architecture and empire in Jamaica (New Haven: Yale University Press, 2016), p. 201.

4 Douglas Hall, In miserable slavery: Thomas Thistlewood in Jamaica, 1750-1786 (London, 1989), p. 252.

5 Daina Ramey Berry and Leslie M. Harris, eds. Sexuality and slavery: reliving intimate histories in the Americas (Athens, 2018). 
6 Trevor Burnard and John Garrigus, The plantation machine: Atlantic capitalism in French Saint-Domingue and British Jamaica (Philadelphia, 2016).

7 Jack P. Greene, Evaluating empire and confronting colonialism in eighteenth-century Britain (New York, 2013), ch. 5.

8 [John Fothergill], Considerations relative to the North American colonies (London, 1765), pp. 40-42.

9 Simon Gikandi, Slavery and the culture of taste (Princeton, 2010), p. 115.

${ }^{10}$ Trevor Burnard, Mastery, tyranny, and desire: Thomas Thistlewood and his slaves in the Anglo-Jamaican world (Chapel Hill, 2004). The diaries are in Thomas Thistlewood's Papers, James Marshall and Marie-Louise Osborn Collection, Beinecke Rare Book and Manuscript Library, Yale University. All references to Thistlewood's diaries are by dates only.

${ }^{11}$ Edward Long, The history of Jamaica ... (3 vols. London, 1774).

12 The modern equivalent would be $£ 38,100$. https://www.measuringworth.com/calculators/ukcompare/relativevalue.php

${ }^{13}$ Orland Patterson, The confounding island: Jamaica and the postcolonial predicament (Cambridge, Mass., 2019), p. 46. See also Trevor Burnard, Jamaica in the age of revolution (Philadelphia, 2020), ch. 3, passim.

${ }^{14}$ David Scott, 'The paradox of freedom: an interview with Orlando Patterson,' Small Axe 17 (2013), pp. 96-242 (quotations pp. 222 and 236).

${ }^{15}$ Edward Long, History of Jamaica ... (3 vols. London: T. Lowndes, 1774), II: pp. 280-1.

${ }^{16}$ Norbert Elias, The civilizing process (Oxford, 1994). 
${ }^{17}$ Doris Garraway, The libertine colony: creolisation in the early French Caribbean (Durham, N.C., 2005), pp. 194-292.

18 Thomas Haskell, 'Capitalism and the origins of the humanitarian sensibility,' American Historical Review 90 (1985), pp. 339-61, 547-66.

${ }^{19}$ Trevor Burnard, 'Powerless masters: the curious decline of Jamaican sugar planters in the foundational period of British 'Abolition,' Slavery \& 'Abolition 32 (2011), pp. 185-98; idem and Richard Follett, 'Caribbean slavery, British antislavery and the cultural politics of venereal disease,' Historical Journal 55 (2012), pp. 427-52.

${ }^{20}$ Peter J. Cain and Anthony G. Hopkins, 'Gentlemanly capitalism and British overseas expansion I: the old colonial system, 1688-1850,' Economic History Review 39 (1986), pp. $501-$

25.

${ }^{21}$ Sarah Yeh, 'Colonial identity and revolutionary loyalty: the case of the West Indies,' in Stephen Foster, ed., British North America in the seventeenth and eighteenth centuries (Oxford, 2013), p. 205 and idem, 'A sink of all filthiness': gender, family, and identity in the British Atlantic, 1688-1763,' The Historian 68 (2006), pp.66-88. Yeh notes, however, that West Indian planters, no matter how they acted on their plantations regarding plantation management, did not embrace a modernizing or progressive identity but insisted on their British identity. For planters as essentially modern, see Burnard and Garrigus, The plantation machine.

${ }^{22}$ Nelson, Architecture and empire, pp. 192, 217. Phil Withington has shown how increased consumption of intoxicants by well-off Englishmen as part of 'wit' casts new light on the 
discourse around civility and excess. Withington, 'Intoxicants and society in early modern England,' Historical Journal 54 (2011), pp. 631-57.

${ }^{23}$ Edward [Kamau] Braithwaite, The development of creole society in Jamaica, 1770-1820 (Oxford, 1970).

${ }^{24}$ David Arnold, The problem of nature: environment, culture and European expansion (Oxford, 1996); idem, The tropics and the traveling gaze: India, landscape, and science, 1800-1856 (Seattle, 2006); Mark Harrison, Medicine in the age of commerce and empire: Britain and its tropical colonies, 1660-1830 (Oxford, 2010); and Mimi Sheller, Consuming the Caribbean: from Arawaks to zombies (London, 2003).

${ }^{25}$ Bryan Edwards, The history, civil and commercial, of the British colonies in the West Indies, (2 vols. London, 1793), II: p. 7; Richard Renny, A history of Jamaica (London, 1807), p. 209.

${ }^{26}$ Burnard, Mastery, tyranny, and desire, p. 75.

27 James Knight, 'The natural, moral and political history of Jamaica and the territories thereon depending,' London, British Library, Long papers, Add. MSS. 12,419, vol. 1, fo. 71.

${ }^{28}$ Moreton, West India customs and manners, p. 61; William Beckford, A descriptive account of the island of Jamaica (2 vols. London, 1790), I, p. 267.

${ }^{29}$ Christer Petley, 'Gluttony, excess and the fall of the planter class,' Atlantic studies 9 (2012), pp. 85-106.

${ }^{30}$ Maria Nugent, Lady Nugent's Journal of her residence in Jamaica from 1801 to 1805 ed. Philip Wright (Kingston, 2002), 1.

${ }^{31}$ Michael Craton, 'Decoding pitchy-patchy: the roots, branches and essence of junkanoo,' Slavery and 'Abolition 16 (1995), pp. 14-44; Kenneth Bilby, “More than meets the eye': African-Jamaican festivities in the age of Belisario,' in T.J. Barringer et al., Art and 
emancipation in Jamaica (New Haven, 2007), pp. 121-36; and Nelson, Architecture and empire (New Haven, 2016), pp. 183-6.

32 John Stewart, A view of the past and present state of the island of Jamaica ... (Edinburgh, 1823), p. 174; Moreton, West India manners and customs, pp. 131-2. See also Brooke N.

Newman, 'Gender, sexuality, and the formation of racial identities in the eighteenth-century Anglo-Caribbean world,' Gender History 22 (2010), pp. 585-602.

${ }^{33}$ Helen Berry, 'Rethinking politeness in eighteenth-century England: Moll King's coffee house and the significance of "flash talk", Transactions of the Royal Historical Society $6^{\text {th }}$ ser. 11 (2001), pp. 63-82.

${ }^{34}$ Gentility differed from hospitality as a means whereby the genteel could make explicit the dividing line between themselves and common people. C. Dallett Hemphill, Bowing to necessities: a history of manners in America, 1620-1860 (New York, 1999), p. 16.

${ }^{35}$ Moreton, West Indian customs and manners, p. 36; Renny, History of Jamaica, pp. 216, 323.

${ }^{36}$ Burnard, Mastery, tyranny, and desire, p. 82; Hall, In miserable slavery, pp. 223, 309.

${ }^{37}$ Nugent, Journal, pp. 45, 55-57, 69-70, 80-81, 88.

${ }^{38}$ Ibid, p. 71.

${ }^{39}$ Moreton, West Indian customs and manners, pp. 165-71.

${ }^{40}$ Robert Charles Dallas, $A$ short journey in the West Indies... (2 vols. London, 1790), I: p. 54.

${ }^{41}$ Mary Turner, 'Slave workers, subsistence, and labour bargaining: Amity Hall, Jamaica, 18051832,' in Ira Berlin and Philip D. Morgan, eds., The slaves' economy: independent production by slaves in the Americas (London, 1991), p. 92. 
${ }^{42}$ Burnard and Garrigus, Plantation machine, pp. 118-9.

${ }^{43}$ Robert T. Dirks, 'The slaves' holiday,' Natural History 84 (1975), pp. 82-91; Justin Roberts, 'The better sort' and 'the poorer sort': wealth inequalities, family formation, and the economy of energy on British Caribbean sugar plantations, 1750-1800,' Slavery and Abolition 35 (2014), pp. 458-73.

${ }^{44}$ Petley, 'Gluttony, excess and the fall of the planter class,' p. 88.

${ }^{45}$ Burnard and Follett, 'Caribbean slavery, British antislavery and the cultural politics of venereal disease.'

${ }^{46}$ Elizabeth A. Bohls, 'The gentleman planter and the metropole: Long's history of Jamaica,' in Gerald Maclean et al., eds., The country and the city revisited: England and the politics of culture, 1550-1850 (Cambridge, 1999), pp. 180-96.

${ }^{47}$ Long, History of Jamaica, II: pp. 261-300.

${ }^{48}$ For a local rebuttal, see Augustus Matthews, The lying hero, or an answer to J.B. Moreton ... (St Kitts, 1793).

${ }^{49}$ Moreton, West Indian customs and manners, p. 36.

${ }^{50}$ Ibid, pp. 174, 178.

${ }^{51}$ Ibid, p. 106.

${ }^{52}$ Burnard, Mastery, tyranny, and desire, p. 82.

${ }^{53} 20$ November 1778, The diary of the Revd. William Jones 1771-1821 ed. O.F. Christie (New York, 1929), pp. 44-45.

${ }^{54}$ Boyd Hilton, A mad, bad, and dangerous people? England 1783-1846 (Oxford, 2006), pp. 174-87; idem, The age of atonement: the influence of evangelicalism on social and economic thought 1795-1865 (Oxford, 1988). 
${ }^{55}$ Compare, for example, Paul Langford, A polite and commercial people: England, 1727-1783

(Oxford 1989) to E.P. Thompson, Whigs and hunters: the origins of the Black Act (London, 1975). For an impassioned revival of late eighteenth-century Britain and its empire as a zone of fierce class contestations, see Peter Linebaugh, Red round globe hot burning: a tale at the crossroads of commons \& closure, of love and terror, of race and class, and of Kate and Ned Despard (Berkeley, 2019).

${ }^{56}$ Vic Gatrell, City of laughter: sex and satire in eighteenth-century London (London, 2006); Erin Mackie, Rakes, highwaymen, and pirates: the making of the modern gentleman in the eighteenth century (Baltimore, 2009); Judith S. Lewis, Sacred to female patriotism: gender, class, and politics in late Georgian Britain (New York, 2000); Valérie Capdeville, 'Gender at stake: the role of eighteenth-century London clubs in shaping a new model of English masculinity,' Culture, Society \& Masculinities 4 (2012), pp. 13-32; Karen Harvey, 'The history of masculinity, circa 1650-1800,' Journal of British Studies 44 (2005), pp. 296-311; and idem,

The little republic: masculinity and domestic authority in eighteenth-century Britain (Oxford, 2012). For the wider context, see Marilyn Morris, Sex, money, \& personal character in eighteenth-century British politics (New Haven, 2014).

${ }^{57}$ Lewis, Sacred to female patriotism, pp. 135-42

${ }^{58}$ Joanna Innes, 'Politics and morals: the reformation of manners movement in later eighteenthcentury England,' in Eckhart Hellmuth, ed., The transformation of political culture: England and Germany in the late eighteenth century (Oxford, 1990), pp. 57-118.

${ }^{59}$ Kate Davison, 'Occasional politeness and gentlemen's laughter in $18^{\text {th }}$ C. England,' Historical 
Journal 57 (2014), pp. 921-45.

${ }^{60}$ Lewis, Sacred to female patriotism, pp. 135-42; Morris, Sex, money \& personal characteristics, pp. 20-21; Elaine Chalus, Elite women in English political life, c. 1754-1790 (Oxford, 2006), ch.3, passim; Leonore Davidoff and Catherine Hall, Family fortunes: men and women of the English middle class, 2d ed. (New York, 2002), introduction, passim.

${ }^{61}$ Joanna Innes, 'Politics and morals: the reformation of manners movement in later eighteenthcentury England,' in Hellmuth, The transformation of political culture, pp. 57-118.

${ }^{62}$ Burnard and Follett, 'Caribbean slavery, British antislavery and the cultural politics of venereal disease.'

${ }^{63}$ Roger Norman Buckley, The British army in the West Indies: society and the military in the revolutionary age (Gainesville, 1988) and David Patrick Geggus, Slavery, war, and revolution: the British occupation of Saint Domingue, 1793-1798 (Oxford, 1982).

${ }^{64}$ Yeh, 'Colonial identity and revolutionary loyalty,' p. 205.

${ }^{65}$ Perry Gauci, William Beckford: First Prime Minister off the London Empire (New Haven, 2013); Sarah Pearsall, “The late flagrant instance of depravity in my family': The story of an Anglo-Jamaican cuckold,' William and Mary Quarterly 60 (2003), pp. 549-82.

${ }^{66}$ Christer Petley, White fury: a Jamaican slaveholder and the age of revolution (Oxford, 2018). For the Caribbean as preciously modern, see David Scott, 'Modernity that predated the modern: Sidney Mintz's Caribbean,' History Workshop Journal 58 (2004), pp. 191-210; Burnard, Jamaica in the age of revolution; and Emily Senior, The Caribbean and the medical imagination, 1764-1834 (Cambridge, 2018). 
${ }^{67}$ Natalie Zacek, 'Cultivating virtue: Samuel Martin and the paternal ideal in the eighteenthcentury English West Indies,' Wadabagei 10 (2007), pp. 8-31; Srividhya Swaminathan, 'A world inverted: political satire and the proslavery argument,' Slavery \& Abolition 41 (2020), pp. 25674; Michael Taylor, 'The British West India interest and its allies, 1823-1833,' English

Historical review 133 (2018), pp. 1478-1511.

${ }^{68}$ James H. Mills and Patricia Barton, 'Introduction,' in idem, Drugs and empire: essays in modern imperialism and intoxication, c. 1500-c.1930 (Basingstoke, 2007), p. 1.

${ }^{69}$ David Hancock, Oceans of wine: Madeira and the emergence of American trade and taste (New Haven, 2009), ch.9 passim.

${ }^{70}$ Ibid, p. 347.

${ }^{71}$ Alan Bewell, Romanticism and colonial disease (Baltimore, 1999), pp. 49-51. See also Mark Harrison, “The tender frame of man': disease, climate and racial difference in India and the West Indies, 1760-1860,' Bulletin of the History of Medicine 70 (1996), pp. 68-93.

${ }^{72}$ Senior, The Caribbean and the medical imagination, ch. 4, passim.

${ }^{73}$ Carolyn Vellenga Berman, Creole crossings: domestic fiction and the reform of modern slavery (Ithaca, 2006), pp. 27-8.

${ }^{74}$ Senior, The Caribbean and the medical imagination, pp. 130.

${ }^{75}$ Fever discourses in the Johnny Newcome cartoons is covered in Candace Ward, Desire and disorder: fevers, fictions, and feeling in English Georgian culture (Lewisburg, PA, 2007). The prints are James Sayers, 'Johnny new-come in the island of Jamaica (London, 1800) and [Abraham James], 'The torrid zone, or blessings of Jamaica,' (London, 1803) ${ }^{76}$ Harald 
Fischer-Tiné, “"The drinking habits of our countrymen”: European alcohol consumption and colonial power in British India,' The Journal of Imperial and Commonwealth history 40 (2012), p. 386; and Robert Travers, 'Death and the nabob: imperialism and commemoration in eighteenth-century India,' Past \& Present 196 (2007), pp. 83-124. ${ }^{77}$ Elizabeth Kolsky, Colonial justice in British India: white violence and the rule of law (Cambridge, 2011).

${ }^{78}$ Harald Fischer-Tiné, Low and licentious Europeans: race, class in white subalternity in colonial India (New Delhi, 2009).

${ }^{79}$ Fischer-Tiné, “ “Drinking habits of our countrymen”,' p. 399.

${ }^{80}$ David Arnold, 'India's place in the tropical world, 1770-1930,' Journal of Imperial and Commonwealth history 26 (1998), pp. 1-21. 